\title{
Abbreviations of Works Cited in the Text
}

\section{Robert Duncan}

$\begin{array}{ll}\text { Bow } & \text { Bending the Bow } \\ \text { FC } & \text { Fictive Certainties } \\ \text { Field } & \text { The Opening of the Field } \\ \text { GWBW } & \text { Ground Work: Before the War } \\ \text { GWII } & \text { Ground Work II: In the Dark } \\ \text { Roots } & \text { Roots and Branches }\end{array}$

T. S. Eliot

CPP The Complete Poems and Plays: 1909-50

H.D. (Hilda Doolittle)

CP Collected Poems: 1912-44

HD Hermetic Definition

Tribute Tribute to Freud

Ted Hughes

CB Cave Birds: An Alchemical Cave Drama 
xx Abbreviations

James Merrill

CLS The Changing Light at Sandover: Including the Whole of the Book of Ephraim, Mirabell's Books of Number, Scripts for the Pageant, and a New Coda, The Higher Keys

REC Recitative: Prose by James Merrill

Sylvia Plath

LH Letters Home: Correspondence, 1950-1963

SP The Collected Poems

Ezra Pound

Cantos The Cantos of Ezra Pound

CEP The Collected Early Poems of Ezra Pound

GB Gaudier-Brzeska

LE Literary Essays of Ezra Pound

Personae Personae: The Shorter Poems .

SR The Spirit of Romance

Trans Translations of Ezra Pound

Wallace Stevens

WS Collected Poems

W. B. Yeats

Auto The Autobiography of William Butler Yeats

Poems The Poems: A New Edition

Vision A Vision: A Reissue with the Author's Final Revisions 
Modernist Alchemy 
